\title{
History and Development of Military Psychology
}

\author{
George R. Mastroianni
}

\section{Contents}

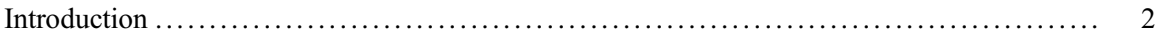

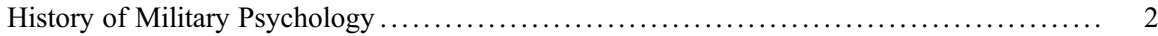

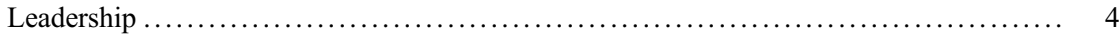

The Industrialization of Warfare and the Growth of Scientific Military Psychology ....... 5

The Development of Military Psychology as a Field and Present Applications ............. 6

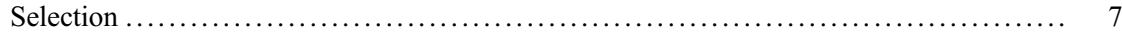

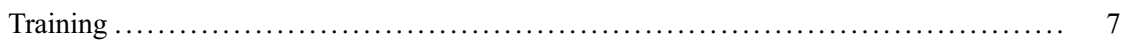

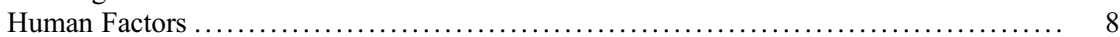

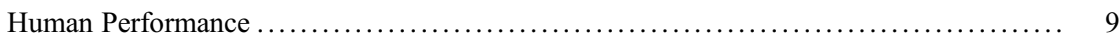

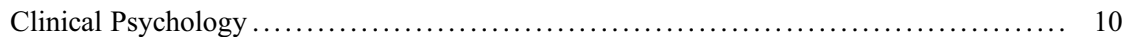

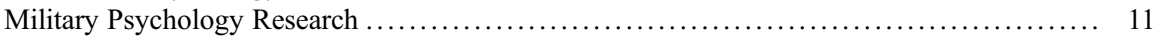

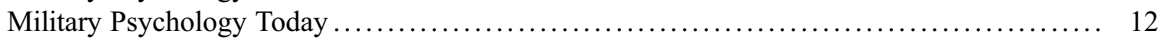

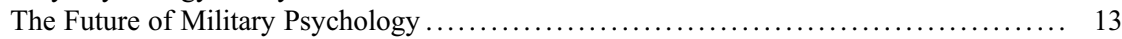

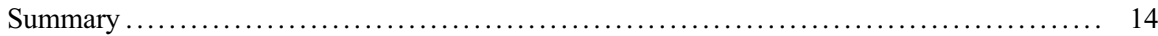

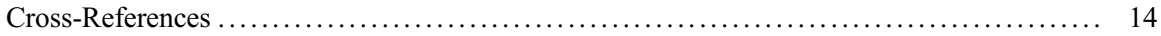

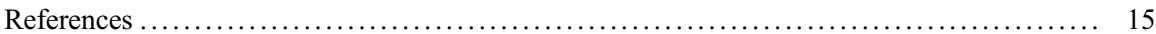

\section{Abstract}

Psychology is widely thought to have emerged as a scientific discipline only quite recently: at the end of the nineteenth century. Psychological thinking had nevertheless been occurring for millennia, and such thinking formed a significant element of Greek philosophy in the centuries before the Common Era. The Greeks, no strangers to war, applied this thinking to military matters, such as learning, motivation, and the roles of environment and heredity in human development. From these beginnings, the systematic study of the unique considerations that arise when humans come together in military undertakings began. The industrialization of warfare that began in the nineteenth century added new

G. R. Mastroianni $(\square)$

United States Air Force Academy, Colorado Springs, CO, USA

e-mail: grm17@psu.edu 
questions and problems, problems which became more urgent just as the novel application of the methods of science to human psychology became institutionalized in universities in the decades before World War I. Today, military psychology is a vibrant and dynamic field that focuses on a core set of stable and enduring areas of study that include leadership, personnel selection, training, human factors, human performance, and clinical psychology. As military technology and the nature of warfare continue to evolve within the context of national and social institutions that are themselves constantly in flux, military psychology will adapt to encompass the new questions and problems brought by these changes.

\section{Keywords}

Military psychology $\cdot$ Military history $\cdot$ Military medicine $\cdot$ Human factors $\cdot$ Human engineering

\section{Introduction}

Psychologists around the world contribute to military institutions and operations as serving members of military forces, as civilian members of defense establishments, and as a broader community of scholars, researchers, and practitioners. Psychology now plays an essential role in many areas of military life, and the discipline is institutionalized in most military establishments. Before exploring the scope and nature of the roles played by military psychology today, it is worthwhile to briefly consider the connection between psychology and the military in historical context.

Most introductory psychology textbooks date the origins of psychology as a scientific discipline to 1876 (or thereabouts), the year that Wilhelm Wundt founded his psychology laboratory in Leipzig. William James' Principles of Psychology appeared in 1890 and became an early and influential work defining the boundaries of the new field. If psychology itself only coalesced as a field in the late-nineteenth century, it stands to reason that there could have been no military psychology before that date because there was no psychology. But if we take a broader view, and accept the long history of reflection about human nature and the practical knowledge about human conduct and affairs accumulated over the centuries as a kind of psychology, then we can identify connections between psychology and military life and affairs long before the end of the nineteenth century.

\section{History of Military Psychology}

One of the earliest sustained discussions of the psychology of military members occurred more than 2000 years ago in several of Plato's dialogues, especially the Republic, which lays out a basic psychology and the psychological development of a military guardian class within the context of an idealized city-state (see Carpenter 2010; Robinson 1995). Plato (trans. 1969) divides the psyche into three parts: a rational part (reason) and two irrational parts, the emotions and the appetites. 
Reason, the weakest part, Plato compares to a charioteer being pulled by the two horses of emotion and appetite. Emotions are distinguished from appetites to the extent that some emotions - e.g., the desire for honors, a sense of pride and shame act as countervailing forces to the appetites. Self-restraint, for example, is understood as the work of emotions like shame or pride subordinating the appetites. While everyone has all three parts of the psyche, one part tends to dominate the other two and motivate one's life course. For most people, the appetites dominate, and they will seek out a pleasant life. Only a tiny minority are ruled by reason, and they will seek out a life of quiet contemplation. But there is a small group in whom the emotions dominate, and they will seek out a life of honor and social status.

In Plato's city, that smaller group in whom emotion rules and who seek a life of honor is selected and trained from a young age to become members of the military guardian class. In addition to physical and martial training, members of the guardian class receive a moral education that satisfies their longing for honors through an identity as guardians of the state and its laws. Their guardian identity would be reinforced and protected from temptation by social arrangements that played doubleduty as reinforcers of group solidarity and morale. The guardian class would live communally in common barracks devoid of luxuries and private property and with women and children of the class being held in common. It is worth noting, as feminist scholars have (e.g., Tuana 1994), that women were also members of the guardian class to be selected, educated, and trained with the men. Finally, any child born into the guardian class without the requisite psychological disposition would be demoted to the appetitive (civilian) class; anyone born to the civilian class who displayed the psychology of a guardian would be promoted into the guardian class.

We can see in Plato's account echoes of the selection, education, and training of today's military professional. Obviously, modern militaries are subordinated to civilian governments, and military members are not forced to live communally. But they are segregated from civilian society during their formative period to develop a military identity that includes distinctive dress, symbols, codes of conduct, ceremonies, and histories. They are encouraged to internalize a specifically military ethos defined by duty, honor, self-discipline, service before self, and to think of themselves as guardians of the state, its people, and its laws (Plato, trans. 1969).

The guardians of Plato's Republic bear a strong resemblance to the ruling class of Sparta, the leader of a coalition of city-states that defeated Athens in the Peloponnesian War. Like all Greeks, the Spartans fought in the phalanx formation, the integrity and success of which depended heavily on the social and psychological bonds between soldiers. The life of every soldier depended on the actions of the soldier to his immediate right. The success of Greek arms was determined in part by the maneuvers taken on the day of battle. But the larger part of the iceberg lay in the years of social, psychological, and cultural conditioning every Spartan soldier experienced. Unlike other Greek city-states, whose armies were composed of citizen-soldiers, Sparta had a professional army (Marrou 1956). At the age of seven, young male Spartiates (members of the military ruling class) were initiated into the agoge, a brutal physical training regimen that prepared them for military training when they became adults. The boys lived in barracks with a troop of other 
boys on a poor diet to encourage them to steal and hunt for food. Once they reached adulthood, the young men were inducted into the Spartan army where they began military training and where they would remain until they were 60 (Cartledge 2003). Contemporaries observed that the long years of martial training made Spartans into a more resilient and disciplined fighting force capable of campaigning longer and harder and performing maneuvers that other Greek armies could not (see, e.g., Xenophon, trans. 1925). The legend of Spartan culture and character have come down through the ages as illustrating the putative ennobling benefits of rigorous discipline, directly connecting individual and social development with military prowess. The very word "Spartan" conjures images of discipline and asceticism, and "laconic" (derived from Laconia, the region in which Sparta was located) describes terse and economical speech for which the Spartans were famous.

The Greeks also understood the effects of warfare on soldiers. Jonathan Shay sees in the Homeric epics an understanding of the effects of combat trauma on soldiers today. Achilles in Vietnam (Shay 1994) and Odysseus in America (Shay 2003) use these ancient texts to explore moral injury (Shay's term) experienced by some veterans as a result of their experiences in battle. Shay's integration of these ideas into therapeutic approaches to help struggling veterans is a direct connection between modern and ancient understandings of military psychology.

Even before the rise of scientific psychology in the late nineteenth century, recognizably psychological principles and practices were applied to military problems. Principles of learning, for example, were applied to ensure the development of needed skills: Repetition and automatization guaranteed that soldiers could still perform under the stress of combat. The Greeks understood that warfare demanded certain concessions to human nature, and they developed efficient and effective fighting forces by integrating military service into a fabric of social, political, and legal systems that enmeshed the individual in a web of relationships that justified, validated, and determined each soldier's role.

\section{Leadership}

Leadership has always been an essential element of a military. Leadership includes motivating soldiers, persuading them of the value of the things for which they are asked to fight, equipping them with the mental and physical tools they need to fight and win. As we have seen, leaders have, since ancient Greek times, used political, social, and cultural bonds to establish the psychological conditions that make the management of fighting forces possible. That fundamentally psychological aspect of warfare continued to be vital after psychology emerged as a scientific discipline in the late nineteenth century. Technological, economic, and political developments that gathered steam at about the same time as psychology's institutionalization would lead to an expansion of psychology's role in selecting, training, and preparing soldiers for military service and war as the twentieth century progressed. While technological developments have played some role in the development of clinical approaches to help soldiers affected by their wartime experiences, Shay's work 
illustrates the essential continuity between ancient and modern times in terms of the psychological effects of combat trauma on soldiers and those around them.

Kurt Lewin, sometimes regarded as the father of modern social psychology, initiated experimental studies of leadership in the late 1930s (Lewin and Lippitt 1938; Lippit 1940). The formal study of leadership as a multi-disciplinary academic subject began to take shape after World War II. An excellent historical summary and survey of contemporary leadership theory may be found in Leadership: Theory and Practice by Peter C. Northouse (2018).

Before the emergence of scientific psychology in the late nineteenth century, there existed at least three domains in military affairs in which pre-scientific psychological thinking and practice were employed: (1) the selection, training, and preparation of soldiers, (2) the use of psychological and social influence to create and sustain cohesive, committed fighting forces (leadership), and (3) an understanding of the effects of combat trauma on soldiers and approaches to ameliorate those effects. We shall see that the disciplinary portfolio of modern military psychology now encompasses an even broader range of concerns, but that these three early areas of military psychological interest remain firmly embedded in modern approaches, as well.

\section{The Industrialization of Warfare and the Growth of Scientific Military Psychology}

Industrialization in the nineteenth century and the mechanization in the twentieth century dramatically transformed warfare. This transformation occurred more quickly and completely in some places than others, but the American Civil War and the First World War were early steps on a trajectory of technological change that would, within the space of little more than a century, move the warrior's perspective from the back of a horse to the seat of a supersonic jet fighter and put levels of destructive power that once could only be amassed by nations at the fingertips of single individuals. It was during the early years of this transition, between the end of the American Civil War and the beginning of the First World War, that scientific psychology became institutionalized.

A comparison of the American Civil War with the First World War reveals the staggering scope of technical innovation in the machinery and methods of war that were underway as psychology was emerging as a scientific discipline. The muzzleloading muskets of the American Civil War were replaced by small-caliber, highvelocity breech-loading bolt-action small arms that could be accurately employed at substantial ranges and could fire several shots without reloading, a process that could be accomplished autonomously by the individual soldier. Machine-guns capable of firing several hundred rounds per minute became available. Balloons were used in a very limited way for aerial observation in the American Civil War, but by the time of the First World War, there was a sophisticated aerial warfare program that included tactical and strategic bombing and aerial operations against naval targets. Railways were used to move troops during the American Civil War, but by the First World War the invention of internal combustion engines led to trucks for mobility and tanks for 
offensive action, though horses continued to play a significant role in warfare through the end of World War II. Poison gas was used as a weapon on a large scale in the First World War.

\section{The Development of Military Psychology as a Field and Present Applications}

The field that we know as military psychology began with the First World War. While the role played by psychologists in World War I was relatively limited, it set the stage for a dramatic expansion of participation by psychologists in the Second World War. Psychology was growing as an academic and scientific discipline, the pace of change in technologies that would soon be applied to military problems was accelerating, and the staggering scope and scale of the conflict ensured that there would be ample opportunity for psychologists to apply their knowledge and skills in the war effort.

By the end of World War II, the general contours of the discipline of military psychology would emerge. It is important to bear in mind that military psychology is a naturally dynamic field. There are core problems and concerns that have always been and will always be part of military psychology, such as human performance under stress. But social and cultural change led to intense interest in racial and gender integration in the military as social and political progress opened military service to groups that had hitherto been excluded. Technological progress has naturally shaped those areas of the discipline that are concerned with the soldiermachine interface. During World War II, these concerns centered on military hardware: "software" as we know it today did not exist then, but producing software that soldiers can use effectively in combat today is an important task to which military psychologists contribute. The very nature of warfare itself shifted after World War II, as large-scale conventional conflict gave way to so-called brushfire wars during the Cold War, limited wars that would not trigger global nuclear conflict. These wars brought new ways of fighting, and new problems to military psychologists. This is all as one would expect, because military psychology is an applied discipline. While there may be (and is) a core set of stable questions and problems confronting military organizations and personnel amenable to psychological study, there will also be questions and problems coming and going as political, social, economic, and technical change alter the military landscape.

What follows is a brief discussion of the core areas of military psychology that arose (or continued to develop) during World War II. The questions, problems, demands, and issues associated with these areas helped frame the development of military laboratories and other organizations, and civilian academic programs related to military psychology in the decades after the war. These areas represent the stable core of issues that have defined military psychology since its emergence as a discipline, and are likely to remain key foci of the discipline for the indefinite future. Military psychology is what military psychologists do, and what military psychologists do is determined by military needs. Military needs change in unpredictable 
ways. Military psychology, then, is the institutionalized capability to apply specialized skills and knowledge to military problems.

\section{Selection}

Technical innovations in the first half of the twentieth century created new demands on the military personnel who would employ the new weapons and tools of warfare. Existing technologies already required a range of skills and abilities. Nearly four million men entered the military as part of mobilization for World War I in the United States. For example, the US population at the time was a bit over 100 million. The diversity in background, health, education, literacy, and social experience in these four million was staggering. Military leaders needed to match this diverse group to a diverse set of jobs as quickly as possible.

The contribution to World War I for which psychologists are best remembered is in the area of personnel selection. In the United States, many prominent psychologists joined the war effort. A group led by Robert Yerkes produced a series of intelligence tests modeled on those developed by Alfred Binet that were administered to large numbers of soldiers upon entry into the service. These tests were called the Army Alpha and Beta tests. The Army Alpha Test was administered to literate soldiers, while those who could not read or write were administered the Beta Test. There was also a provision for individual examination. The intelligence tests produced for the American armed forces were used extensively in schools in the decades after World War I. Psychologists helped in selection efforts elsewhere, as well: Paul Fitts reported that "the first psychological testing center for the armed forces was established in Germany in 1915 for the selection of motor transport drivers" (Koonce 1984).

Aviation was a prominent and visible example of a new military capability that introduced an unfamiliar and comparatively complex technology into warfare, a technology that made significant demands on its human users. It became clear quite early that while a fairly large proportion of recruits and draftees might be trained to load and fire rifle, flying an airplane was a different matter: Some were much more likely to be successful than others, and the cost of putting the wrong person in the cockpit could be quite high. The involvement of psychologists in the selection and training of aircrew occurred as early as the World War I (Monacis 2007) and aviation psychology remains today one of the major subfields of military psychology.

\section{Training}

As military technology became ever more complex, the development of effective and efficient training systems became more and more important. Training methods were developed and evaluated by psychologists, and programs of instruction were optimized to produce the best performance with the lowest investment in time, money, and personnel. Defense establishments expanded dramatically in a very 
short time during World War II, placing staggering demands on training systems and organizations to satisfy the demands of the rapidly growing forces. Technological innovation continued to create new equipment and systems that brought new training demands: Radios were not widely used in World War I by ground or air forces, but provided the backbone for tactical communication in World War II, for example. The war years produced a blizzard of innovative new technology: Devices like radar and sonar were brought into service as practical and valuable equipment, but each new invention or development brought with it demands for new training.

Psychologists contributed new technologies to training: Fred Keller, a close associate of B. F. Skinner, designed operant-learning-based training programs for learning of Morse Code, for example. Such reward-based systems, in which the learner typically works through training materials that break the tasks to be learned into manageable sub-tasks that must be mastered before moving on to the next, may now be found in many e-learning applications. Keller's Personalized Systems of Instruction, or PSI, also called the Keller Plan (Eyre 2007), which incorporated principles derived from studies of operant conditioning, later saw limited use in education. While PSI never achieved significant penetration in education, elements of the system are often found in military training programs and settings.

\section{Human Factors}

Psychologists played an important role in the selection and training of personnel, and often the roles for which individuals were being selected and trained involved the use and operation of equipment of various degrees of novelty and complexity. In general, the equipment development process did not provide a role for the participation of psychologists or others whose expertise lay with those factors related to the utilization of the equipment by the intended user rather than the equipment itself. During and after World War II, however, the equipment design and testing process in many military establishments began to include a consideration of the "human factor." The logic of this development was simple. Adapting and matching the features of a device or piece of equipment to the user early in the development process (rather than trying to adapt the user to the equipment after the fact) resulted in better performance and safety. Out of this consideration have emerged several fields of specialization related to human factors, human engineering, human factors engineering, and ergonomics (Casey, 1998; Norman, 1988).

Controls and displays were an early area of emphasis, sometimes leading to the pejorative characterization of early human factors efforts as "knobology." The configuration and placement of switches, knobs, dials, levers, buttons and so on chosen for a piece of equipment can have dramatic effects on both safety and performance. Human sensory capabilities are such that information displays, such as gauges, indicator lights, and computer screens, must be carefully configured to ensure that the size, color, clarity, contrast, are such that human beings can process the information needed form them under operational conditions. 
Operating complex equipment involves perception and motor input and responses that interact directly with the design of controls and displays, but there is also an important cognitive element that must be taken into account. Human information-processing structures our interaction with equipment. Some items of information may need to be checked or monitored more often than others, for example. Information may be needed and responses may need to be organized into sequences that would make some structural and functional features more congruent with human cognitive processing than others.

Aircraft displays offer an excellent illustration of these considerations. Operating an aircraft involves the simultaneous monitoring and management of many systems: flight controls, engine status, fuel management, and navigation, to name only a few. The "real estate" on an aircraft instrument panel is crowded with controls and displays related to these and other systems. How should these displays be configured? Maintaining control of the attitude, altitude, and speed of the aircraft are very high on the pilot's to-do list, and so the primary flight instruments providing information on these parameters are normally presented prominently and centrally in the pilot's view, often in the same spatial relationship to one another across aircraft types. This makes it easy for pilots to develop a habitual and repetitive cross-check to maintain situational awareness of these vital parameters.

Other systems may be just as important contributors to flight safety, but may monitor items that change much more slowly than aircraft flight parameters. Certain engine-status indicators may be examples of items that are checked less often, and so may occupy a more peripheral location. Modern aircraft contain elaborate warning systems that alert pilots when values begin to deviate from the desired range. The pilot's attention will be drawn to the appropriate information, which might provoke a look at a related instrument: this natural sequence of actions should be supported by a deliberate placement of sources of information that will facilitate, rather than hinder, the acquisition of needed information quickly.

\section{Human Performance}

World War I was the first major conflict to occur after scientific psychology appeared, and the earliest instance of psychologists officially recruited to support the military and the war effort. But the roles played by psychologists were still quite limited. World War II brought about a massive mobilization of all sectors of society in support of the war effort. Psychologists were part of this total effort, and the breadth of contributions of psychologists during the war laid the foundations for the development of military psychology once victory had been achieved.

World War II was a global war, fought in a wide range of climatic and environmental conditions, year-round for nearly 6 years. The explosion in new technology placed soldiers in conditions in which humans had previously had little or no experience: Aviation and submarine warfare had been in their infancy during World War I, for example, but played important roles in World War II. The effects of factors such as altitude, isolation, prolonged exposure to heat, cold, humidity, 
aridity, and a host of other environmental and physical stressors on human performance came to be of great interest to a military establishment confronted with the need to conduct world-wide operations. Since World War II, military forces have engaged in more varied conflicts in diverse climates and environments, such as Korea, Vietnam, the Middle east, and Southwest Asia.

Planning and preparing for operations in diverse environments requires information about the performance capabilities of soldiers in these different circumstances. Soldiers operating in very hot environments, for example, face significant physical challenges. Understanding how these challenges may affect soldier performance is crucial to leaders who must plan operations that are consistent with soldier capabilities. Soldiers operating in severe cold have nutritional requirements that are significantly different from those of soldiers working in warmer conditions: leaders must be aware of these special requirements and incorporate these considerations into their planning. In the United States, the US Army Research Institute for Environmental Medicine operates specialized facilities that permit the recreation of extreme climatic conditions in the laboratory, permitting researchers to study the effects of environmental stressors on human performance. Similarly, Defense Research and Development Canada uses specialized facilities that can simulate extreme environmental conditions varying in altitude and temperature, among others, to enable the study of the impact of a wide array of stressors on human performance in operationally relevant scenarios. Such studies are used to develop models of human performance that can help leaders ensure that soldiers are properly equipped and supplied for the demands that they face, and that operational plans are formulated with a clear view of human performance capabilities in mind.

\section{Clinical Psychology}

Military service, and especially the experience of combat, can lead to positive personal growth. Many people who experience war integrate their experiences into positive and productive lives. But many also suffer devastating and long-lasting consequences as a result of their experiences in the military. We have already mentioned Jonathan Shay's use of Homer as a way of addressing some of these consequences in a contemporary context. The now-common term posttraumatic stress disorder (PTSD), which became an official diagnosis in 1980, had its origins in attempts to understand the struggles of Holocaust survivors and later Vietnam veterans (Herzog 2019). But we can also identify earlier attempts to grapple with the mental health consequences of the experience of combat and trauma.

During the American Civil War, soldiers who suffered from mental and behavioral symptoms that we might now suspect as symptoms of PTSD were thought to have something called "soldier's heart" or "nostalgia." During World War I, soldiers with such symptoms were described as suffering from "shell shock." In World War II, "battle fatigue" or "combat fatigue" were terms often applied in these circumstances. These terms suggest that the emergence of these symptoms in soldiers was often attributed to organic causes: physical damage associated with the experience of 
warfare. Sometimes, though, the soldier himself was blamed, as these symptoms were interpreted as signs of weakness, laziness, or feeble-mindedness. Psychiatric casualties, as they were sometimes called, were treated far forward, rather than evacuated to the rear, with the goal of rapidly returning them to duty. Psychologizing or medicalizing the soldier's symptoms was thought to prolong and intensify the episode and to impede eventual recovery. The term "battle fatigue" implied a reversible state brought on by prolonged stress, and treatment was organized along these lines.

Clinical psychology did not really become well-institutionalized until after World War II, and disciplinary boundaries were not as rigid then as they seem to be now. Gustave Gilbert, the psychologist who administered Rorschach tests to the war criminals at Nuremberg, for example, was trained in experimental psychology. Many initiatives that would now seem firmly related to clinical psychology were undertaken by a more varied group of professionals then. Psychiatrists, psychologists, and others, for example, were sometimes called upon to offer psychological assessments of foreign leaders or culture. At least two such efforts to analyze Adolf Hitler were commissioned, one of which led to the eventual publication of the somewhat sensational book The Mind of Adolf Hitler.

The Office of War Information orchestrated information campaigns within the United States and in the theaters of war. These efforts straddled the boundaries of what we might now think of as social psychology and clinical psychology. Films, posters, and other publications were created to buttress and sustain morale on the home front and among the fighting troops and to erode morale in enemy societies and formations. The dominance of Freudian thinking at the time ensured that these efforts were guided in part by psychoanalytic formulations.

Social psychologists were drawn into this effort to monitor opinions and attitudes, again both on the home front and overseas. Before and after the end of the war, psychologists interviewed German prisoners of war to assess morale and attitudes, helped guide the Military Government rebuilding of Germany, and studied the effects of the strategic bombing campaign on German citizens and society.

\section{Military Psychology Research}

The five areas discussed above constitute the core of military psychology. In many countries there is an elaborate infrastructure of military-oriented research establishments that address these specific areas. In the United States, many (though certainly not all) of the research institutions and laboratories that address military psychologyrelated issues are part of the military medical research establishment. This is especially true of the human performance, some human factors, and clinical domains. Others, such as selection and training, are more likely to be integrated into personnel-related institutions and laboratories. These are broad generalizations, and there are many exceptions. The specific circumstances and challenges faced by countries may help shape the contours of their research infrastructure. 


\section{Military Psychology Today}

The topic areas listed in the foregoing section can still be considered an accurate summary of the main areas of interest in military psychology. There has nevertheless been a great deal of change in military affairs since World War II. The rise of irregular warfare that occurred as the Cold War rendered general conflict unthinkable, followed by the emergence of terrorism or asymmetric warfare as a global threat have brought new problems and questions to the table. Racial and gender integration have altered military organizations, many of which are now smaller and are often all-volunteer forces. Family issues, the integration of LGBT service members, deployment and re-integration, suicide, PTSD, traumatic brain injury, remote warfare - these are challenges that confront contemporary military psychologists that were not on the radar at the turn of the twenty-first century, let alone the middle of the twentieth century.

Military psychologists continue to work in core issue areas, but now also address themselves to new problems. One way to track these evolutionary changes in military psychology is to examine the contents of handbooks of the discipline periodically produced by major academic publishers. Such handbooks generally include a guess at the future of military psychology but are especially useful as snapshots in time, opening a window onto the topics confronting military psychologists in the years immediately preceding the publication of the handbook.

The 1992 Handbook of Military Psychology edited by Reuven Gal and David Mangelsdorff offers a look at the field at the end of its first half-century, before the attacks of September 11, 2001, would set in motion a chain of events that would inevitably expand the scope of military psychology. The topics covered in this 1992 handbook exhibit considerable continuity with the topics that had their origins in World War II and before. The section headings in this volume were selection, classification and placement, human factors, environmental factors, individual and group behavior, clinical and organizational applications, and special issues. These section headings track well with the major areas of military psychologists at the end of World War II.

A pair of handbooks published two decades later illustrate the changes in military psychology occasioned by the evolving global war on terror. The Oxford Handbook of Military Psychology (Laurence and Matthews, 2012) and Military Psychology: Clinical and Operational Applications (Kennedy and Zillmer, 2012) included several topics which had not appeared in earlier handbooks. The Oxford Handbook, for example, included ethics in interrogation, terrorism, LGBT issues, and families, in addition to the more traditional topics addressed in military psychology. These additions reflect some changes in military establishments themselves, such as the opening of service to LGBT personnel that has now taken place in most Western militaries and growing recognition of the role of families in military life, as increasing professionalization and decreasing reliance on draftees or conscripts in many services has increased the proportion of service members with families.

These changes also reflect the changing character of military operations after September 11, 2001. Terrorism and terrorists naturally have become an object of 
interest to military psychologists, and the involvement of psychologists in the interrogation process provoked a searching appraisal and evaluation of the role played by military and civilian psychologists in these interrogations. The Oxford volume included a chapter on suicide prevention. International concern with the problem of military suicide has led to increased efforts by military psychologists to better understand this tragic phenomenon (NATO, 2018).

Three more recent handbooks, the Military Psychologists's Desk Reference (Moore and Barnett, 2013), the Handbook of Military Psychology: Clinical and Organizational Practice (Bowles and Bartone, 2017), and the Routledge International Handbook of Military Psychology and Mental Health (Kumar, 2019) address suicide in the military, family issues, and issues related to the service of women in military organizations. The Military Psychologist's Desk Reference contains 67 chapters organized into four areas: history and culture, specialties and programs, ethical and professional issues, and clinical research and practice. The 2017 handbook by Bowles and Bartone also addresses the issue of sexual assault in military forces, a problem that has attracted more attention from military psychologists. This book also contains a very useful series of summaries of developments in military psychology from several different nations.

\section{The Future of Military Psychology}

Because military psychology is an applied discipline, military psychology is what military psychologists do. Some of the things that military psychologists do today are things that they have been doing from the very beginning of the discipline. Selection, classification, and training, and human factors and human engineering continue to be important parts of military psychology because the problems they address are essential: Militaries will always need to bring personnel into their organizations, will always need to classify, assign, train, evaluate, and promote them, and will always need new technology. The problems confronting military personnel psychologists may change, both because of changing military needs and because of the dynamic nature of the societies from which those militaries are drawn, but the general issues remain the same.

Human factors, human engineering, environmental factors, and human performance are likewise areas that have exhibited considerable stability as components of military psychology. Technology continues to evolve, and the military continues to be a major contributor to technical change and a major consumer of new technology. Technology changes, but new technology must still be effectively integrated into military services.

Other things military psychologists do are responsive to changes in military affairs - for example, suicide, sexual assault, LGBT issues, families, torture, and terror. Sometimes entirely new issues arise to confront military psychologists. The introduction of unmanned aerial vehicles, or remotely-piloted aircraft, for example, brought both traditional issues, such as human factors, to military psychologists, but also new problems associated with service members sometimes performing wartime functions in peacetime environments. What new issues and problems will challenge 
military psychologists in the future cannot be known, but we can expect that military psychologists will apply the time-tested methods and approaches to address those issues and problems.

\section{Summary}

While military psychology only became formally institutionalized in the early twentieth century, we can trace interest in many of the core issues in the discipline back to antiquity. Changes in the nature of warfare and technological developments have altered and expanded the topics addressed by military psychologists. Military psychology began a dramatic expansion and institutionalization during and after the First World War. As an applied discipline, military psychology is what military psychologists do, and what military psychologists do is dictated by the constantly changing demands placed on military organizations and individuals as warfare and technology continue to evolve.

\section{Cross-References}

Anthropological Study of the Military

- Application of Military History

- Artificial Intelligence

$\checkmark$ Conflict Management

- Counterinsurgency Operations

$\checkmark$ Decision Making

- Human Interaction with/through Technology

- Humanities' Influence on Military Sciences

$\checkmark$ Information Systems

- Leadership in Extremis

- Military and Popular Culture

- Military Behaviour and Ethics

- Military Families: Challenges and Opportunities in Turbulent Times

- Military Leader and Leadership Development

- Military Personnel

- Military Profession

- Military Sociology

- Military Training, Education, and Socialization

- Military Women: Changes in Representation and Experiences

- Network Centric War

- Peace Support/building/enforcement Operations

- Recruitment and Retention

- Social Sciences' Influence on Military Sciences

$\checkmark$ Weaponry

D What is Military Leadership?

- What is Military Technology? 


\section{References}

Bowles, S., \& Bartone, P. T. (Eds.). (2017). Handbook of military psychology: Clinical and organizational practice. Berlin: Springer Verlag.

Carpenter, R. (2010). The military character of Plato's Republic. Unpublished doctoral dissertation, University of Auckland.

Cartledge, P. (2003). Spartans: The world of the warrior-heroes of ancient Greece. New York: Overlook Press.

Casey, S. (1998). Set Phasers on Stun: And other true tales of design, technology, and human error. Santa Barbara: Aegean Publishing.

Eyre, H. L. (2007). Keller's personalized system of instruction: Was it a fleeting fancy or is there a revival on the horizon? The Behavior Analyst Today, 8(3), 317-324.

Herzog, D. (2019). Cold War Freud. Cambridge: Cambridge University Press.

James, W. (1890). The principles of psychology, in two volumes. New York: Henry Holt and Company.

Laurence, J. H., \& Matthews, M. D. (2010). Oxford handbook of military psychology. New York: Oxford University Press.

Lewin, K., \& Lippitt, R. (1938). An experimental approach to the study of autocracy and democracy: A preliminary study. Sociometry, 1, 292-300.

Lippitt, R. (1940). An experimental study of the effect of democratic and authoritarian group atmospheres. University of Iowa Studies in Child Welfare, 16, 43-195.

Marrou, H. I. (1956). A history of education in antiquity (George Lamb Trans.). New York: Sheed and Ward.

Moore, B. A., Barnett, J., \& e. (2013). Military psychologists' desk reference. Oxford: Oxford University Press.

NATO. (2018). Military suicide prevention: Report prepared for NATO leadership, NATO STO Technical Report HFM-218. Retrieved from https://www.sto.nato.int/publications/STO\%20Technical\% 20Reports/Forms/Technical\%20Report\%20Document\%20Set/docsethomepage.aspx?ID=4019\&Fold erCTID=0x0120D5200078F9E87043356C409A0D30823AFA16F6010066D541ED10A62C40 B2AB0FEBE9841 A61\&List $=92 \mathrm{~d} 5819 \mathrm{c}-\mathrm{e} 6 \mathrm{ec}-4241$-aa4e-57bf918681b1\&RootFolder $=\%$ 2Fpublications\%2FSTO\%20Technical\%20Reports\%2FSTO-TR-HFM-218

Norman, D. A. (1988). The design of everyday things. New York: Perseus.

Northouse, P. C. (2018). Leadership: Theory and practice. New York: Sage.

Plato. (1969). Republic. In Paul Shorey (Ed. And Trans.), Plato in twelve volumes. Cambridge, MA: William Heinemann. Retrieved from http://www.perseus.tufts.edu/

Robinson, D. N. (1995). An intellectual history of psychology (3rd ed.). Madison: University of Wisconsin Press.

Shay, J. (1994). Achilles in Vietnam: Combat trauma and the undoing of character. New York: Atheneum.

Shay, J. (2003). Odysseus in America: Combat trauma and the trials of homecoming. New York: Scribner.

Tuana, N. (Ed.). (1994). Feminist interpretations of Plato. University Park: University of Pennsylvania Press.

Xenophon. (1925). Constitution of the Lacedaimonians. In C. Marchant and G. W. Bowersock (Eds. And Trans.), Xenophon in seven volumes. Cambridge, MA; William Heinemann. Retrieved from http://www.perseus.tufts.edu/hopper/text?doc=Perseus\%3Atext\%3A1999.01.0210\% 3Atext $\% 3$ DConst.+Lac

\section{Suggestions for Further Reading}

Bowles, S., \& Bartone, P. T. (Eds.). (2017). Handbook of military psychology: Clinical and organizational practice. Berlin: Springer.

Casey, S. (1998). Set Phasers on Stun: And other true tales of design, technology, and human error. Santa Barbara: Aegean Publishing. 
Gal, R., \& Mangelsdorff, D. (Eds.). (1992). Handbook of military psychology. Chichester: Wiley. Kennedy, C. H., \& Zillmer, E. A. (2012). Military psychology: Clinical and operational applications. New York: Guilford Press.

Koonce, J. M. (1984). A brief history of aviation psychology. Human Factors, 26(5), 499-508.

Kumar, U. (Ed.). (2019). Routledge international handbook of military psychology and mental health. Abingdon-on-Thames: Routledge Publishers.

Laurence, J. H., \& Matthews, M. D. (2010). Oxford handbook of military psychology. New York: Oxford University Press.

Monacis, L. (2007). Psychology and the armed forces. Revista de Historia de la Psicologia, 28(2/3), 167-172.

Moore, B. A., Barnett, J., \& e. (2013). Military psychologists' desk reference. Oxford: Oxford University Press.

Norman, D. A. (1988). The design of everyday things. New York: Perseus.

Open Access This chapter is licensed under the terms of the Creative Commons Attribution 4.0 International License (http://creativecommons.org/licenses/by/4.0/), which permits use, sharing, adaptation, distribution and reproduction in any medium or format, as long as you give appropriate credit to the original author(s) and the source, provide a link to the Creative Commons license and indicate if changes were made.

The images or other third party material in this chapter are included in the chapter's Creative Commons license, unless indicated otherwise in a credit line to the material. If material is not included in the chapter's Creative Commons license and your intended use is not permitted by statutory regulation or exceeds the permitted use, you will need to obtain permission directly from the copyright holder.

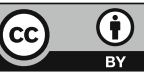

